\title{
Polar Bear (Ursus maritimus) Behavior near Icebreaker Operations in the Chukchi Sea, 1991
}

\author{
Mari A. Smultea, ${ }^{1}$ Jay Brueggeman, ${ }^{2}$ Frances Robertson, ${ }^{3}$ Dagmar Fert $1,{ }^{4}$ Cathy Bacon, ${ }^{5}$ \\ Richard A. Rowlett ${ }^{6}$ and Gregory A. Green ${ }^{7}$
}

(Received 12 April 2015; accepted in revised form 28 January 2016)

\begin{abstract}
Increasing interactions of polar bears (Ursus maritimus) with human activity, combined with impacts of climate change, are of critical concern for the conservation of the species. Our study quantifies and describes initial reactions and behaviors of polar bears observed from an icebreaker during summer 1991 at two exploratory drilling sites (near sites drilled in 2015) located in the Chukchi Sea $175 \mathrm{~km}$ and $312 \mathrm{~km}$ west of Barrow, Alaska. Polar bear behavior was described using continuous sampling of six predetermined focal group behavior states (walking, running, swimming, resting, feeding or foraging, unknown) and six behavioral reaction events (no reaction, walking away, running away, approaching, vigilance [i.e., watching], unknown). Forty-six bears in 34 groups were monitored from the Robert LeMeur (an Arctic Class 3 icebreaker) for periods of five minutes to 16.1 hours. Significantly more bear groups reacted to icebreaker presence $(79 \%)$ than not $(21 \%)$, but no relationship was found between their reactions and distance to or activity of the icebreaker. Reactions were generally brief; vigilance was the most commonly observed reaction, followed by walking or running away for short ( $<5$ minutes) periods and distances $(<500 \mathrm{~m})$. Eleven percent of bear groups approached the vessel. No significant difference was found between reactions when cubs were present and those when cubs were absent. Despite the limited sample sizes, these findings are relevant to assessing potential impacts of resource development and shipping activities on polar bears, especially given the sparsity of such information in the face of growing human activity in the Arctic offshore areas. Overall, climate change is leading to longer and more extensive open-water seasons in the Arctic and therefore to increasing marine traffic-more vessels (including icebreakers) for a longer time each year over a wider area.
\end{abstract}

Key words: polar bear; Ursus maritimus; icebreaker; behavior; reaction; Arctic; human activity; icebreaking; Chukchi Sea; drilling

RÉSUMÉ. Les interactions de plus en plus grandes entre les ours polaires (Ursus maritimus) et l'activité humaine, alliées aux incidences du changement climatique, constituent une préoccupation critique en matière de conservation de l'espèce. Notre étude permet de quantifier et de décrire les réactions et les comportements initiaux des ours polaires observés à partir d'un brise-glace à l'été 1991 à deux sites de forage d'exploration (près de chantiers forés en 2015) dans la mer des Tchouktches, à $175 \mathrm{~km}$ et à $312 \mathrm{~km}$ à l'ouest de Barrow, en Alaska. Le comportement des ours polaires a été décrit en recourant à l'échantillonnage en continu de six états de comportement prédéterminés pour le groupe ciblé (marcher, courir, nager, se reposer, manger ou chercher de la nourriture et comportement inconnu) et de six réactions comportementales aux événements (aucune réaction, s'en aller à la marche, s'en aller à la course, s'approcher, faire preuve de vigilance [c'est-à-dire observer], réaction inconnue). Quarante-six ours faisant partie de 34 groupes ont été surveillés à partir du Robert LeMeur (un brise-glace de l'Arctique de classe 3) pendant des périodes allant de cinq minutes à 16,1 heures. Fait important, plus de groupes d'ours ont réagi à la présence du brise-glace $(79 \%)$ que pas réagi $(21 \%)$, mais aucune relation n'a pu être établie entre leurs réactions et la distance ou l'activité du brise-glace. De manière générale, les réactions étaient brèves. La vigilance était la réaction la plus souvent observée, suivie du fait de s'en aller en marchant ou de s'en aller à la course pendant de courtes ( $<5$ minutes) périodes et distances $(<500 \mathrm{~m})$. Onze pour cent des groupes d'ours se sont approchés du vaisseau. Aucune différence importante n’a été relevée entre les réactions, qu'il y ait des oursons ou non. Malgré la taille restreinte des échantillons, ces constatations ont de la pertinence dans l'évaluation des incidences potentielles des activités de mise en valeur et de transport des ressources sur les ours polaires, surtout compte tenu de la rareté de telles données à la lumière de l'activité humaine croissante dans les zones

\footnotetext{
${ }^{1}$ Smultea Sciences, PO Box 256, Preston, Washington 98050, USA; Marine Mammal Behavioral Ecology Group,

Texas A\&M University at Galveston, Pelican Island, Galveston, Texas 77553, USA; mari@smulteasciences.com

${ }^{2}$ Canyon Creek Consulting, 1147 21st Avenue East, Seattle, Washington 98112, USA

${ }^{3}$ Marine Mammal Research Unit, Institute for Oceans and Fisheries, University of British Columbia, Vancouver, British Columbia V6T 1Z4, Canada

${ }^{4}$ Ziphius EcoServices, 8112 Springmoss Drive, Plano, Texas 75025, USA

51616 Quails Nest Drive, Fort Worth, Texas 76177, USA

${ }^{6}$ PO Box 7386, Bellevue, Washington 98008, USA

${ }^{7}$ Owl Ridge Natural Resource Consultants, 6407 Brayton Drive, Suite 204, Anchorage, Alaska 99507, USA

(C) The Arctic Institute of North America
} 
extracôtières de l'Arctique. Dans l'ensemble, le changement climatique mène à des saisons navigables plus longues et plus étendues dans l'Arctique. Par conséquent, le trafic maritime s'accentue en ce sens qu'il y a plus de vaisseaux (brise-glace y compris) pendant de plus longues périodes chaque année, sur de plus grandes surfaces.

Mots clés : ours polaire; Ursus maritimus; brise-glace; comportement; réaction; Arctique; activité humaine; déglaçage; mer des Tchouktches; forage

Traduit pour la revue Arctic par Nicole Giguère.

\section{INTRODUCTION}

Global warming and increasing human activities are changing the Arctic environment, and with these changes, the polar bear (Ursus maritimus) faces increasing challenges to survival. The U.S. Chukchi and Bering Sea stocks of polar bear are listed as threatened under the U.S. Endangered Species Act, as depleted under the U.S. Marine Mammal Protection Act, and as vulnerable on the International Union for the Conservation of Nature's Red List. Polar bears are ice obligates, preferring dynamic ice-edge habitats, including ice leads and polynyas (Stirling, 1997), inhabited by their preferred prey, the ringed seal (Pusa hispida) and the bearded seal (Erignathus barbatus) (Thiemann et al., 2008; Cherry et al., 2011). Since the polar bear depends on diminishing Arctic ice habitats for feeding and breeding (e.g., Stirling and Derocher, 1993; Amstrup, 2003; Durner et al., 2009), the species has been the focus of international study for the last few decades, particularly with regard to understanding and predicting the effects of climate change (Bromaghin et al., 2015). However, little has been published about the impacts on polar bears of offshore petroleum exploration activities, including shipping and icebreakers (Peacock et al., 2011; Wilson et al., 2014). Icebreaking vessels (icebreakers) are used to break up and manage (i.e., push away) ice. They are critical to ensuring the safety of other vessels and drill rigs during polar oil and gas development activities by impeding encroaching ice that can damage this equipment and endanger personnel.

Changes in Arctic sea ice have resulted in renewed interest for industrial development and shipping-activities that were previously limited both spatially and temporally (Huntington, 2009; Wilson et al., 2014). Offshore industrial developments, both past and present, overlap with known polar bear range, particularly within $40 \mathrm{~km}$ of the coast (Schliebe et al., 2006; Wilson et al., 2014). This overlap is predicted to increase as such development expands and the Arctic Northwest Passage opens to shipping and other vessel traffic. Icebreakers, an essential component of both industrial development and shipping in the Arctic region, have been specifically highlighted as a major potential source of disturbance for polar bears (Wiig et al., 1996).

Existing documentation of polar bear reactions to vessel traffic, particularly icebreakers, is mostly opportunistic and unpublished. Such information is important for assessing potential human-related impacts on polar bears, given the increasing ongoing, planned, and proposed offshore and coastal oil and gas development in Arctic regions (Huntington, 2009; Peacock et al., 2011). Icebreaking operations may disturb denning habitat, affect polar bear migrations, and influence prey availability (Schliebe et al., 2006; Huntington, 2009). The associated noise disturbance may affect mating, hunting, prey, and denning activities (Wiig et al., 1996). Icebreaking operations and onboard garbage-burning and cooking odors may also attract polar bears, both because of the curious nature of polar bears (Stirling, 1988; Derocher, 2012) and because icebreaking operations create artificial leads that can result in temporary local increases in biological productivity, including that of polar bear prey (Stirling, 1988, 1997; Wiig et al., 1996). The potential impacts of increased shipping and expanded industrial development in the Arctic have led the Polar Bear Specialist Group to recommend that parties to the International Agreement on the Conservation of Polar Bears take appropriate measures to monitor, regulate, and mitigate ship traffic impacts on polar bears and their habitat (Vongraven et al., 2012). Furthermore, under the U.S. Endangered Species Act and Marine Mammal Protection Act, human activity that may result in behavioral harassment, harm, injury, or death to animals is prohibited unless specifically permitted by the U.S. Fish and Wildlife Service with accompanying mitigation, monitoring, and reporting requirements. Understanding the behavioral reactions of polar bears to icebreakers is thus an integral and legally required component of obtaining permits in U.S. waters, and implementing appropriate and effective monitoring and mitigation strategies. The Draft Polar Bear Conservation Management Plan (USFWS, 2015) states that there is a lack of direct quantifiable impacts to polar bears from oil and gas activities, suggesting that better understanding of such activities, including icebreaker impacts, could affect recovery and management planning.

In this paper, we summarize short-term polar bear reactions to an icebreaker on the basis of data collected during a marine mammal monitoring program associated with exploratory drilling operations at two remote oil prospects in the Chukchi Sea in 1991 (Brueggeman et al., 1992). Our objective was to systematically quantify and describe the initial behavioral reaction and subsequent behaviors of polar bears within view of the icebreaker. Such monitoring of polar bear behavior was required as part of a Letter of Authorization issued by the U.S. Fish and Wildlife Service (USFWS) permitting behavioral take of polar bears. 


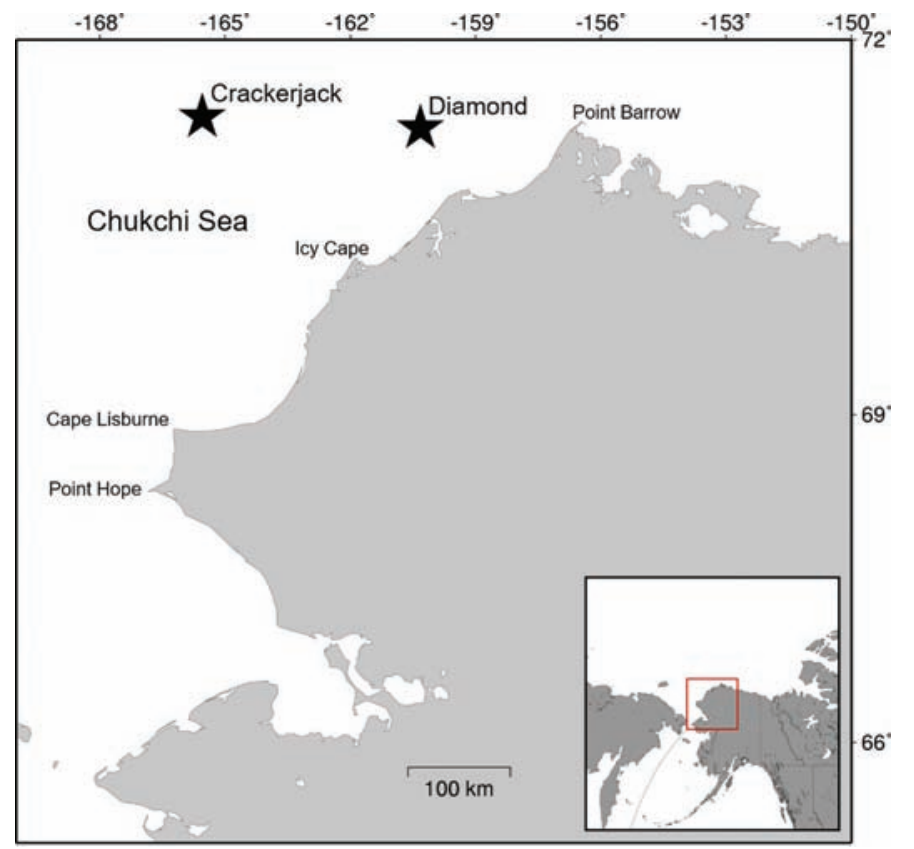

FIG. 1. Location of the Crackerjack and Diamond oil drilling prospects $(\star)$ in the Chukchi Sea, Alaska, where polar bears were observed from the icebreaker Robert LeMeur in 1991.

\section{METHODS}

\section{Study Area and Nature of Operations}

The Crackerjack and Diamond prospect drill sites are located in the Alaskan Chukchi Sea, approximately $324 \mathrm{~km}$ and $175 \mathrm{~km}$ west of Point Barrow, Alaska (Fig. 1). Exploratory drilling and icebreaker operations took place at Crackerjack from 22 September to 11 October 1990 and from 5 July to 30 August 1991, and at Diamond from 31 August to 5 October 1991. Observations of polar bears reported here were collected during the 1991 periods from the Robert LeMeur, an Arctic Class 3 icebreaker (length of $83 \mathrm{~m}$ ). This icebreaker was the primary supply vessel supporting the stationary drillship. Two secondary supply vessels with icebreaking capabilities and a supply-spill response barge were also part of the vessel contingent supporting the stationary drillship. These vessels were required because of the offshore location and often partially ice-covered conditions in the vicinity of the exploratory drilling operations. The three smaller vessels generally remained relatively close to or within view of the drillship, while the Robert LeMeur usually stayed farther away to prevent large floes of ice from endangering the stationary drillship.

\section{Polar Bear Observation Methods}

We observed polar bears from the bridge of the icebreaker during all daylight periods with Beaufort sea state less than 6 as the vessel conducted routine operations (Table 1). During summer, two trained biological observers were aboard the icebreaker to cover the nearly 24 hours of daylight, alternating continuous four-hour watch periods. During autumn's reduced daylight, only one observer was on board, alternating between continuous four-hour watches and 30-minute breaks for meals and rest. Observers used the naked eye and Fujinon $7 \times 50$ reticle binoculars to scan for polar bears and observe bear behavior across the $270^{\circ}$ view afforded through the bridge windows. Whenever possible, distances to animals were determined by using reticles on the binoculars aligned with the water horizon (see Lerczak and Hobbs, 1998). When no horizon was visible because of fog, the observer estimated distance to bears. A radial angle to the sighting was obtained by aligning the zero degree mark on a navigation protractor with the bow of the vessel and recorded to the nearest degree. At the approximate eye height above the sea ice of the observers on the bridge $(14 \mathrm{~m})$, the distance to the horizon was $14.4 \mathrm{~km}$. A group was defined as one or more bears behaving similarly within 10 adult bear body lengths of one another (i.e., approximately 20 m; Stirling, 2009). Age class (i.e., group composition) was determined visually by size and relative size (Table 2).

\section{Behavioral Sampling}

Continuous focal group sampling using pre-defined behavior states and events (Altmann, 1974; Martin and Bateson, 2007) was used to document the behavior of bears. Data were recorded on hard copy data sheets using an ethogram of behavior states and reaction events (Table 3). Behavior states were defined as walking, running, swimming, resting, and foraging or feeding. Bear reactions were classified as no reaction, walking away, running away, approaching, and displaying vigilance. Reaction distance was defined as either the distance at the time when a reaction was first observed or, when no reaction was observed, as the closest observed point of approach. Ad libitum sampling (Altmann, 1974) was used to record additional detailed notes about bear behavior and nearby activities. At the beginning and end of each sighting, whenever behavior state or reaction changed, and each time observation conditions changed notably, we noted the following variables: time, latitude and longitude, group size, number of cubs and subadults, distance from icebreaker to bear(s), behavior state, reaction, icebreaker activity, percent ice cover within a 180-degree view in front of the vessel, Beaufort sea state (when appropriate), and visibility in kilometers. We assumed that bear group behavior state did not change except as noted in accordance with the field data collection protocol. Overall bear group activity was calculated by summing the duration of all behavior states of all bear groups under observation, as recorded in the field notes.

Icebreaker operations were categorized into the following activities: transiting, maneuvering, drifting, ice breaking, and managing ice (Table 1). For our investigation of effects on polar bear reactions, icebreaker activities were pooled into two main operational categories: normal running operations (consisting of transiting, maneuvering, and 
$180 \bullet$ M.A. SMULTEA et al.

TABLE 1. Definitions of routine icebreaker operations and activities.

\begin{tabular}{|c|c|c|}
\hline Icebreaker operation & Icebreaker activity & Definition \\
\hline \multirow[t]{3}{*}{ Normal running } & Transiting & $\begin{array}{l}\text { Moving along a course among ice floes or in open } \\
\text { water without having to push or break ice. }\end{array}$ \\
\hline & Maneuvering & Positioning the ship during routine operations. \\
\hline & Drifting & Drifting along ice or in open water, usually to monitor ice movement. \\
\hline \multirow[t]{2}{*}{ Ice management } & Ice breaking & $\begin{array}{l}\text { Breaking large ice floes while moving along a course } \\
\text { within the ice margin, typically during ice reconnaissance. }\end{array}$ \\
\hline & Managing ice & Pushing ice or splitting small ice floes, typically near the drillship. \\
\hline
\end{tabular}

TABLE 2. Definitions of polar bear age classes.

\begin{tabular}{|c|c|c|}
\hline Age class & Age (years) & Body size \\
\hline Adult & $>5$ & Full-sized bear. \\
\hline Subadult & $2.5-5$ & Approximately two-thirds the size of an adult. Could be determined only if a larger adult bear was nearby. \\
\hline Yearling & $1-2.5$ & Approximately one-half the size of the closely accompanying adult presumed to be the mother. \\
\hline Cub-of-the-year (COY) & $<1$ & Approximately one-third (or less) the size of the closely accompanying adult presumed to be the mother. \\
\hline Undetermined & Unknown age & \\
\hline
\end{tabular}

drifting) and ice management operations (ice breaking and managing ice; Table 1).

\section{Data Analysis}

A total of 34 polar bear groups from 1991 were available for analysis of information that included distance to sightings, behavior state, and reaction information. Bears were observed from the icebreaker at distances ranging from $4 \mathrm{~m}$ to $3.53 \mathrm{~km}$. Twenty-seven groups of 37 bears were observed to exhibit possible reactions to the presence of the icebreaker, while seven groups of nine bears did not react. For analysis purposes, all 34 bear group observations were pooled into three categories: vigilance, approach, or movement away from the icebreaker. Data were categorized also by icebreaker operations (normal running or ice management), vessel distance, and whether or not cubs were present. Summary statistics were computed separately for the following: (1) bear groups that reacted to icebreaker presence vs. groups that did not react, (2) groups observed to react to the icebreaker during normal running vs. groups that reacted during ice management operations, and (3) groups with cubs observed to react to the icebreaker vs. groups without cubs that also displayed reactions.

We used a series of statistical tests to investigate the effects of the activity and distance of the icebreaker on whether or not a bear sighting (i.e., group) reacted. Binomial tests were used to determine whether the icebreaker's presence had a significant effect on bears' reaction or non-reaction. A Kruskal-Wallis test was used to investigate the effect of vessel distance on whether bears reacted or not. Fisher's exact tests were used to assess whether vessel activity or the presence or absence of cubs had a significant effect on whether a bear was observed to react or not. Fisher's exact tests were used over chi-squared contingency tests because of small sample sizes. For those bear groups that did react, the Wilcoxon-Mann-Whitney U-test was used to determine whether there was a significant difference between groups in the mean reaction distance and whether vessel activity state or cub presence had a significant effect on the mean reaction distance of observed bear groups.

\section{RESULTS}

We observed a total of 46 polar bears in 34 groups during the 1991 Chukchi Sea operations period from 6 July to 30 September. Most sightings were of lone bears $(67 \%$, $n=24$ ), followed by pairs ( $n=8$ groups) and groups of three bears $(n=2$; Table 4$)$. Nine groups of two or more individuals with known composition consisted of a female and one or two cubs-of-the-year (COY) or yearlings, for a total of six COY and five yearlings. The actual number of unique individual animals was unknown, as some individuals may have been re-sighted on different days or during different sightings from the icebreaker. Mean estimated ice cover where the 34 bear groups were observed ranged from $10 \%$ to $90 \%($ mean $=44.0 \%, \mathrm{SD}=15.20)$.

The mean distance at which bear groups were initially seen was $1059 \mathrm{~m}(n=34$ groups, $\mathrm{SD} \pm 671 \mathrm{~m}$, range $=$ $10-4036 \mathrm{~m})$. Most bear groups $(72 \%, \mathrm{n}=21)$ were initially seen at distances of over $500 \mathrm{~m}$, and $82 \%$ (28 of the total 34 groups) were seen within $1500 \mathrm{~m}$. Bears were within view of observers for less than $5 \%(56 \mathrm{~h})$ of the 1173 hours over which monitoring took place. Overall, $32 \%(n=11)$ of the 34 bear groups were observed during brief ( $5 \mathrm{~min}$ ) passes by the transiting vessel, while $36 \%(\mathrm{n}=12)$ were observed for 10 to $50 \mathrm{~min}$, and the remaining $32 \%(n=11)$ for 1 to 16.1 hours. Eleven groups of bears were considered to have experienced extended exposure times of more than one hour, and five bear group encounters lasted more than two hours. These extended exposure times occurred while the vessel was drifting and occasionally managing ice. The majority of polar bear groups $(71 \%, n=24)$ were seen while the vessel was transiting and nearly exclusively when ice was nearby. The remaining groups were seen while the vessel was maneuvering, drifting, ice breaking, and managing ice; vessel activity was not recorded for one group. 
TABLE 3. Definitions of polar bear behavior states and reactions to the icebreaker.

\begin{tabular}{|c|c|}
\hline Behavior state/reaction & Definition \\
\hline \multicolumn{2}{|l|}{ Polar bear behavior states: } \\
\hline Walking & Slow gait \\
\hline Running & Fast gait \\
\hline Swimming & Moving through the water \\
\hline Resting & $\begin{array}{l}\text { Sitting or lying prone in the same spot with head on the ground or paws, with legs sprawled out or front legs tucked under the } \\
\text { body, with flank and hindquarters on the ground, or curled up, often sleeping with eyes closed (after Øritsland, 1970). }\end{array}$ \\
\hline Feeding/foraging & $\begin{array}{l}\text { Observed eating prey (seal, walrus, or whale carcass). Also includes apparent hunting or foraging without moving (e.g., } \\
\text { staring for long periods at a breathing hole in the ice). }\end{array}$ \\
\hline \multicolumn{2}{|c|}{ Bear reactions to the icebreaker: } \\
\hline No reaction & No obvious change in behavior \\
\hline Walking away & Obvious movement away from the vessel at a slow pace (walk or slow swim speed) \\
\hline Running away & Obvious movement away from the vessel at run speed or at fast swim speed, creating whitewater (fleeing) \\
\hline Approaching & Movement toward the vessel \\
\hline Displaying vigilance & $\begin{array}{l}\text { A head lift interrupting ongoing bear activity, involving visual scanning of the surroundings beyond the immediate vicinity } \\
\text { (Dyck and Baydack, 2004). This includes watching the vessel or sniffing the air, usually with the nose elevated above the ears. }\end{array}$ \\
\hline
\end{tabular}

TABLE 4. Summary statistics for all bear groups, detailing the number of groups in each category, mean distance (m) at first reaction, standard error, and range of distance (m) at first reaction, as observed from the Robert LeMeur icebreaker vessel in the Chukchi Sea in 1991.

\begin{tabular}{lcccc}
\hline \hline Category & No. of groups & mean $(\mathrm{m})$ & SE & Range (m) \\
\hline No reaction: & 7 & 1122 & 425.9 & $150-3528$ \\
Reaction: & 27 & 820 & 119.4 & $99-2346$ \\
$\quad$ All & 7 & 809 & 213.9 & $342-1757$ \\
With cubs & 20 & 823 & 145.8 & $99-2346$ \\
No cubs & 18 & 755 & 149.8 & $99-2346$ \\
Normal running operations & 9 & 948 & 201.1 & $120-1757$ \\
Ice management operations & & & & \\
\hline \hline
\end{tabular}

\section{Bear Group Reactions}

More (79\%) of the 34 observed bear groups reacted to the icebreaker than not, and this difference was significant (Binomial test, $p=0.0008$; Table 4). However, we did not detect a significant difference in the distance to the vessel for those bears that were observed to react $($ mean $=820 \mathrm{~m})$ versus those bears that were not observed to react (mean $=1122 \mathrm{~m})$ (Wilcoxon-Mann-Whitney U-test: $\mathrm{W}=97, p=$ 0.934). For those bears that did presumably react, the initial reaction distance ranged from 99 to $2346 \mathrm{~m}$ away (Table 4). However, no significant relationship was found between bear reaction and distance to the icebreaker (KruskalWallis test, $\left.\chi^{2}=0.016, \mathrm{df}=1, p=0.898\right)$, icebreaker activity (Fisher's exact test, $p=0.645$, odds ratio $=0.34$ ), or cub presence (Fisher's exact test, $p=1$, odds ratio $=1.14$ ). The most common reaction was vigilance $(50 \%, n=17)$, followed by approaching or moving away $(29 \%, n=10)$, while $21 \%(n=7)$ showed no reaction to the icebreaker.

Bear reactions varied with the type of icebreaker activity. The most commonly observed reaction during icebreaker transit was vigilance. Walking away and running away were seen only while the vessel was actively moving to manage or break ice (and never while the vessel was drifting). This movement away tended to be brief in duration $(<5 \mathrm{~min})$ and short in distance $(<500 \mathrm{~m})$, after which bears resumed walking or resting. Neither vessel activity nor cub presence was found to be significantly related to mean observed bear reaction distance (vessel: $\mathrm{W}=95, p=0.49$; cub: $\mathrm{W}=72, p=0.94)$. Focal behavior sessions occurred during $38.4 \mathrm{~h}$ with 34 polar bear groups and session duration ranged from $5 \mathrm{~min}$ to $16.1 \mathrm{~h}$ per group. Observed bear groups spent most of their time resting (64\%), followed by walking (28\%), swimming (6\%), running (1\%), and feeding or foraging $(1 \%)$.

\section{DISCUSSION}

Despite the increasing temporal and spatial overlap of polar bears with many active and planned industrial developments in the Arctic (Schliebe et al., 2006), this is the first study to investigate effects of icebreaker presence and activity on polar bears. Results from our small sample size (34 bear groups) in a limited geographical area indicate that polar bears seen during summer-autumn 1991 changed their behaviors in the icebreaker's presence. Vigilance was the most common behavioral reaction observed among polar bears. Of the nine groups of females with cubs, $78 \%$ exhibited behavioral changes to the icebreaker's presence, with no significant difference between their mean reaction distance and that of non-cub groups. Although no relationship was found between reactions and distance to vessel, vessel activity, or cub presence, small sample sizes and low associated statistical power presumably limited our ability to assess statistical differences. 
Overall, observed reactions tended to be brief: bears usually resumed their previous activity, including resting and feeding or foraging, within $5 \mathrm{~min}$. For example, when bears were observed to move away, the movement generally involved short distances and tended to occur when the icebreaker was closer to the bear and engaged in ice breaking or managing ice. Our observations are comparable to those from other offshore drilling sites (Stirling, 1988), suggesting that polar bears' reactions to icebreaker operations appear to be short term. This is consistent with other accounts indicating that polar bears, even denning individuals, are not typically overtly disturbed by, or are tolerant of, most human-related activities (summarized in USFWS, 2008). During both our 1991 study and similar studies conducted in the same region in 1990 (Brueggeman et al., 1991), some bears showed no reaction to the icebreaker's presence: they continued to feed, rest, or swim as the icebreaker passed by. Our observations suggest that polar bears initially reacted to the icebreaker but subsequently appeared to habituate to it.

Polar bear reactions we observed were likely related to icebreaker sounds as well as to visual, olfactory, and prey attraction aspects of the icebreaker's presence. The measured in-air hearing sensitivity of polar bears (Nachtigall et al., 2007; Owen and Bowles, 2011) overlaps with the known frequencies of sounds produced by the Robert LeMeur, most of them related to propeller cavitation while pushing against ice (Richardson et al., 1995). Three of five observed bear group reactions while the vessel was ice breaking involved walking or running away, possibly in response to the associated loud noise or physical ice disturbance, or both. However, of four observed approach reactions, one occurred while the icebreaker was actively managing ice. Another approach involved a bear that stood on its hind limbs, placed its forepaws on the drifting vessel's hull, and sniffed the air while garbage burned onboard, an apparent response to olfactory cues. During summer-autumn 1990, two of 23 polar bears in the same Chukchi Sea region approached our same 1991 icebreaker (Brueggeman et al., 1991). An indirect attraction to our vessel may have been the channel formed by the icebreaker moving through ice, which has been reported to attract pinniped bear prey as well as polar bears (Stirling, 1988; Derocher, 2012). Other researchers have also noted similar attraction behavior by polar bears in response to human activities (e.g., Stirling, 1988; Shideler, 1993; Leck et al., 2004; Harwood et al., 2005; Gerwick, 2007). Studies suggest that polar bear reactions vary with the level and extent of human activity as well as bear sex, activity, and prey availability (Stirling, 1988; Dyck and Baydack, 2004; Anderson and Aars, 2008).

Vigilance in polar bears is a common behavioral reaction to human activities. Mills et al. (2010:630) defined vigilance as "alert observation to detect objects or events in the surrounding environment." Vigilance is a motor act corresponding to behaviors that include head lifting and visual scanning (Quenette, 1990). During our study, vigilance was the most commonly seen bear response (46\%) to the icebreaker transiting, drifting, and managing ice. It was also the most frequently recorded behavioral response during a polar bear monitoring study at the same region in 1990 (Brueggeman et al., 1991). Although we observed some polar bear groups approach the icebreaker, others slowly moved away or stopped their behavior to watch the vessel, displaying vigilance. Similarly, a significantly higher frequency of vigilance behavior occurred among polar bears exposed to tundra vehicles in Churchill, Manitoba (Dyck and Baydack, 2004). Polar bears approached by snowmobiles in Svalbard also displayed vigilance-like behaviors, as well as moving away, sometimes for extended periods of time (Anderson and Aars, 2008).

Interrupting an animal's activity may increase energetic costs (Watts et al., 1991; Mills et al., 2010). Polar bears exhibited vigilance and interrupted rest in response to human wildlife viewing activities, reactions equated to anti-predator responses and potentially increasing polar bear energy expenditure (Watts et al., 1991; Dyck and Baydack, 2004). Vigilance behavior may also interrupt hunting and feeding opportunities for polar bears. Although energetic costs are likely negligible if behavioral responses do not involve movement (Watts et al., 1991), Dyck and Baydack (2004) suggested that prolonged head lifting motion and maintaining the head at shoulder level could increase energy expenditure. However, polar bears appear to habituate to the presence of human activities over time (e.g., Dyck and Baydack, 2004; Smith et al., 2007). Our results indicate that polar bears most often reacted with vigilance, and though these reactions were brief and occasional and sometimes the same bear reacted multiple times, the reactions waned over time. This fact suggests that initial responses were short-lived, and bears soon returned to their previous behavior despite continued icebreaker presence.

\section{Study Limitations}

A number of factors limit interpretation and applicability of our study results, including temporally restricted observations, small sample sizes, viewing distance, and the relatively small size of the Robert LeMeur compared to most other icebreakers. In addition, data were collected outside the primary feeding and mating period and may not represent behavior during other periods. Our observations occurred only from the icebreaker and only during summer-autumn of one year (July-October 1991), when sea ice is usually at minimum extent. Examination of year-round polar bear use of the Chukchi Sea Planning Area (CSPA) designated for oil and gas development found that habitat use by non-denning adult females varied spatially and temporally, with highest probability of use during ice retreat (May-July) and growth periods (October-December) (Wilson et al., 2014). Polar bears may be more vulnerable to disturbance during sea ice advance, when they can access more productive shallow continental shelf habitat (Wilson et al., 2014). 
Our assessment of polar bear behavioral responses to the icebreaker's presence was further limited by the small sample size of 34 groups and associated low statistical analysis power. We were thus unable to determine whether distance, icebreaker activity, or cub presence affected behavioral responses. However, we did determine that polar bears displayed some form of behavioral response to icebreaker presence.

Results were also limited by the observer's field of view (up to 3 or $4 \mathrm{~km}$ from the icebreaker). It is possible that bears beyond this distance reacted to the icebreaker by moving away before we could see them. For example, reindeer and caribou responded to human activity at distances and regional scales well beyond the view of local field observers (Vistnes and Nellemann, 2008). Additionally, in other studies female polar bears with cubs were reported to have both greater (Anderson and Aars, 2008) and lesser (Dyck and Baydack, 2004) distances and levels of response than adult males or lone females.

It should also be noted that the Robert LeMeur's shaft horsepower rating of 9600 Brake Horsepower (BHP) is considerably lower than the rated maximum horsepower of 60000 BHP for U.S. Polar Class and many larger Canadian icebreakers (Malme et al., 1989). Thus, bear reactions to other icebreakers could be different from those we observed.

\section{CONCLUSIONS}

The potential impact of icebreakers on polar bears is poorly understood, and currently only limited information is available on potential impacts or how to minimize them (Perham, 2005; USFWS, 2008). Our study indicates that polar bears most commonly reacted to icebreaker presence by watching (vigilance), then returning to previous behavior, a reaction that requires relatively little energy expenditure when infrequent and brief, as in the reactions we observed. Conservatively, best management practices should be designed to minimize impacts of human activities on polar bears, and especially on the factors and behaviors considered most critical to survival, such as cub presence, nursing, feeding and foraging, and prey availability.

\section{ACKNOWLEDGEMENTS}

Marine mammal monitoring was funded by Shell Western E\&P, Inc., and Chevron U.S.A. We thank our observers, Catherine Swanson, John Burns, David Volsen, and C. Edward Bowlby, and our data collection analyst Rich Grotefendt. The monitoring program was conducted under Marine Mammal Protection Act permit no. 670. We would also like to thank the anonymous reviewers, whose suggestions greatly improved the paper, our editor, Julie Hopkins, and our mapmaker, Dave Steckler.

\section{REFERENCES}

Altmann, J. 1974. Observational study of behavior: Sampling methods. Behaviour 49(3):227-267. http://dx.doi.org/10.1163/156853974X00534

Amstrup, S.C. 2003. Polar bear (Ursus maritimus). In: Feldhamer, G.A., Thompson, B.C., and Chapman, J.A., eds. Wild mammals of North America: Biology, management, and conservation, 2nd ed. Baltimore, Maryland: John Hopkins University Press. $587-610$.

Anderson, M., and Aars, J. 2008. Short-term behavioural response of polar bears (Ursus maritimus) to snowmobile disturbance. Polar Biology 31:501 - 507. http://dx.doi.org/10.1007/s00300-007-0376-x

Bromaghin, J.F., McDonald, T.L., Stirling, I., Derocher, A.E., Richardson, E.S., Regehr, E.V., Douglas, D.C., Durner, G.M., Atwood, T., and Amstrup, S.C. 2015. Polar bear population dynamics in the southern Beaufort Sea during a period of sea ice decline. Ecological Applications 25(3):634-651.

http://dx.doi.org/10.1890/14-1129.1

Brueggeman, J.J., Volsen, D.P., Grotefendt, R.A., Green, G.A., Burns, J.J., and Ljungblad, D.K. 1991. Final Report Shell Western E\&P Inc. 1990 Walrus Monitoring Program: The Popcorn, Burger, and Crackerjack prospects in the Chukchi Sea. Prepared for Shell Western E\&P Inc., Houston, Texas by Ebasco Environmental, Bellevue, Washington.

Brueggeman, J.J., Grotefendt, R.A., Smultea, M.A., Green, G.A., Rowlett, R.A., Swanson, C.C., Volsen, D.P., et al. 1992. 1991 Marine Mammal Monitoring Program (walrus and polar bear), Crackerjack and Diamond prospects, Chukchi Sea. Prepared for Shell Western E\&P Inc., Houston, Texas and Chevron U.S.A, Inc. by Ebasco Environmental, Bellevue, Washington.

Cherry, S.G., Derocher, A.E., Hobson, K.A., Stirling, I., and Thiemann, G.W. 2011. Quantifying dietary pathways of proteins and lipids to tissues of a marine predator. Journal of Applied Ecology 48(2):373-381.

http://dx.doi.org/10.1111/j.1365-2664.2010.01908.x

Derocher, A.E. 2012. Polar bears: A complete guide to their biology and behavior. Baltimore, Maryland: John Hopkins University Press.

Durner, G.M., Douglas, D.C., Nielson, R.M., Amstrup, S.C., McDonald, T.L., Stirling, I., Mauritzen, M., et al. 2009. Predicting 21st-century polar bear habitat distribution from global climate models. Ecological Monographs 79(1):25-58. http://dx.doi.org/10.1890/07-2089.1

Dyck, M.G., and Baydack, R.K. 2004. Vigilance behaviour of polar bears (Ursus maritimus) in the context of wildlifeviewing activities at Churchill, Manitoba, Canada. Biological Conservation 116(3):343-350.

http://dx.doi.org/10.1016/S0006-3207(03)00204-0

Gerwick, B.C., Jr. 2007. Construction of marine and offshore structures, 3rd ed. Boca Raton, Florida: CRC Press. http://dx.doi.org/10.1201/9781420004571

Harwood, L.A., McLaughlin, F., Allen, R.M., Illasiak, J., Jr., and Alikamik, J. 2005. First-ever marine mammal and bird observations in the deep Canada Basin and Beaufort/Chukchi Seas: Expeditions during 2002. Polar Biology 28(3):250-253. http://dx.doi.org/10.1007/s00300-004-0691-4 
Huntington, H.P. 2009. A preliminary assessment of threats to Arctic marine mammals and their conservation in the coming decades. Marine Policy 33(1):77-82. http://dx.doi.org/10.1016/j.marpol.2008.04.003

Leck, C., Tjernström, M., Matrai, P., Swietlicki, E., and Bigg, K. 2004. Can marine micro-organisms influence melting of the Arctic pack ice? EOS Transactions 85(3):25-32. http://dx.doi.org/10.1029/2004EO030001

Lerczak, J.A., and Hobbs, R.C. 1998. Calculating sighting distances from angular readings during shipboard, aerial, and shore-based marine mammal surveys. Marine Mammal Science 14(3):590-599. http://dx.doi.org/10.1111/j.1748-7692.1998.tb00745.x

Malme, C.I., Miles, P.R., Miller, G.W., Richardson, W.J., Roseneau, D.G., Thomson, D.H., and Greene, C.R., Jr. 1989. Analysis and ranking of the acoustic disturbance potential of petroleum industry activities and other sources of noise in the environment of marine mammals in Alaska. Report No. 6945. OCS Study U.S. Minerals Management Service 89-0006.

Martin, P., and Bateson, P. 2007. Measuring behavior: An introductory guide, 3rd ed. Cambridge: Cambridge University Press. http://dx.doi.org/10.1017/CBO9780511810893

Mills, D.S., Marchant-Forde, J.N., McGreevy, P.D., Morton, D.B., Nicol, C.J., Phillips, C.J.C., Sandøe, P., and Swaisgood, R.R. eds. 2010. The encyclopedia of applied animal behavior and welfare. Cambridge: Cambridge University Press.

Nachtigall, P.E., Supin, A.Y., Amundin, M., Röken, B., Møller, T., Mooney, T.A., Taylor, K.A., and Yuen, M. 2007. Polar bear Ursus maritimus hearing measured with auditory evoked potentials. Journal of Experimental Biology 210:1116-1122. http://dx.doi.org/10.1242/jeb.02734

Øritsland, N.A. 1970. Temperature regulation of the polar bear (Thalarctos maritimus). Comparative Biochemistry and Physiology 37(2):225-233. http://dx.doi.org/10.1016/0010-406X(70)90547-5

Owen, M.A., and Bowles, A.E. 2011. In-air auditory psychophysics and the management of a threatened carnivore, the polar bear (Ursus maritimus). International Journal of Comparative Psychology 24(3):244-254.

Peacock, E., Derocher, A.E., Thiemann, G.W., and Stirling, I. 2011. Conservation and management of Canada's polar bears (Ursus maritimus) in a changing Arctic. Canadian Journal of Zoology 89(5):371-385.

http://dx.doi.org/10.1139/z11-021

Perham, C. 2005. Proceedings: Beaufort Sea Polar Bear Monitoring Workshop, 3-5 September 2003, Anchorage, Alaska. OCS Study U.S. Minerals Management Service 2005-034.

Quenette, P.-Y. 1990. Functions of vigilance behavior in mammals: A review. Acta Oecologica 11(6):801-818.

Richardson, W.J., Greene, C.R., Jr., Malme, C.I., and Thomson, D.H. 1995. Marine mammals and noise. San Diego, California: Academic Press.

Schliebe, S., Evans, T., Johnson, K., Roy, M., Miller, S., Hamilton, C., Meehan, R., and Jahrsdoerfer, S. 2006. Range-wide status review of the polar bear (Ursus maritimus). Anchorage, Alaska: U.S. Fish and Wildlife Service.
Shideler, D. 1993. Attraction to human activity. In: Truett, J.C., ed. Guidelines for oil and gas operations in polar bear habitats. OCS Study MMS 93-0008. 17-24.

Smith, T.S., Partridge, S.T., Amstrup, S.C., and Schliebe, S. 2007. Post-den emergence behavior of polar bears (Ursus maritimus) in northern Alaska. Arctic 60(2):187-194. http://dx.doi.org/10.14430/arctic243

Stirling, I. 1988. Attraction of polar bears Ursus maritimus to offshore drilling sites in the eastern Beaufort Sea. Polar Record 24(148): $1-8$. http://dx.doi.org/10.1017/S0032247400022282

- 1997. The importance of polynyas, ice edges, and leads to marine mammals and birds. Journal of Marine Systems 10(14):9-21. http://dx.doi.org/10.1016/S0924-7963(96)00054-1

. 2009. Polar bear (Ursus maritimus). In: Perrin, W.F., Würsig, B., and Thewissen, J.G.M., eds. In: Encyclopedia of marine mammals, 2nd ed. San Diego, California: Elsevier/ Academic Press. 888-890.

http://dx.doi.org/10.1016/B978-0-12-373553-9.00204-2

Stirling, I., and Derocher, A.E. 1993. Possible impacts of climatic warming on polar bears. Arctic 46(3):240-245.

http://dx.doi.org/10.14430/arctic1348

Thiemann, G.W., Iverson, S.J., and Stirling, I. 2008. Polar bear diets and Arctic marine food webs: Insights from fatty acid analysis. Ecological Monographs 78(4):591-613.

http://dx.doi.org/10.1890/07-1050.1

USFWS (U.S. Fish and Wildlife Service). 2008. Biological Opinion for Bureau of Land Management for the Northern Planning Areas of the National Petroleum Reserve-Alaska. Fairbanks: USFWS.

—. 2015. Polar bear (Ursus maritimus) Conservation Management Plan, Draft. Anchorage: U.S. Fish and Wildlife, Region 7. 89 p.

Vistnes, I., and Nellemann, C. 2008. The matter of spatial and temporal scales: A review of reindeer and caribou response to human activity. Polar Biology 31(4):399-407. http://dx.doi.org/10.1007/s00300-007-0377-9

Vongraven, D., Aars, J., Amstrup, S., Atkinson, S.N., Belikov, S., Born, E.W., DeBruyn, T.D., et al. 2012. A circumpolar monitoring framework for polar bears. Ursus 23(sp2):1-66. http://dx.doi.org/10.2192/URSUS-D-11-00026.1

Watts, P.D., Ferguson, K.L., and Draper, B.A. 1991. Energetic output of subadult polar bears (Ursus maritimus): Resting, disturbance and locomotion. Comparative Biochemistry and Physiology 98A(2):191-193.

Wiig, Ø., Belikov, S.E., Boltunov, A.N., and Garner, G.W. 1996. Selection of marine mammal valued ecosystem components and descriptions of impact hypotheses in the Northern Sea Route Area. International Northern Sea Route Programme (INSROP) Working Paper 40. 70 p.

Wilson, R.R., Horne, J.S., Rode, K.D., Regehr, E.V., and Durner, G.M. 2014. Identifying polar bear resource selection patterns to inform offshore development in a dynamic and changing Arctic. Ecosphere 5(10): 136.

http://dx.doi.org/10.1890/ES14-00193.1 